\title{
EN TORNO AL MAGISTERIO DE EUGENIA GÁLVEZ VÁZQUEZ
}

\section{Ma Jesús Viguera Molins}

Creo que mi generación, hasta donde puedo yo sentirlo, ha vivido de forma demasiado acuciante el tiempo, como creo que la generación anterior, que representa ahora Eugenia Gálvez Vázquez -porque con ella estoy desde estas líneas tratando-, lo vive con más naturalidad.

Éste quizás sería un punto de separación, en las evoluciones generacionales, que nunca son iguales, de modo que para ella tendrá distinto sentido que yo le diga que quiero y no quiero encontrarme hoy, en la evocación de los treinta y tres años con exactitud -estamos en octubrehasta hoy transcurridos desde que yo la conocí, individualizada y realzada por su categoría docente, y ella me conoció a mí, gregaria y difusamente, dada mi condición de discente, en la clase de "Lengua Árabe III" de la entonces llamada 'Facultad de Filosofía y Letras' de la Universidad Complutense, en su Departamento de Árabe e Islam.

En octubre de 1965 tuvimos la fortuna de que Eugenia Gálvez se incorporara al equipo de profesores del Departamento de Árabe e Islam, y de que apareciera en nuestra clase, y de que se dedicara, con su estilo y su saber, a procurar enseñarnos desde octubre a junio. La primera impresión que me produjo (que nos produjo, porque creo que lo apreciamos todos, y mi compañera, desde los tiempos de aquella clase, Clara Thomas de Antonio puede corroborarlo) fue que esta profesora tenía la cualidad de ser moderna.

Y esta modernidad tuvo un sentido muy importante. Eugenia Gálvez era 'actual' en su modo de plantear el objetivo de la docencia y era 'actual' en su manera de relacionarse con nosotros, alumnos. Voy a intentar explicar algo más de ambas sensaciones nuestras acerca de su bien entendida modernidad.

Empiezo por lo segundo, por la dimensión personal de aquella situación: Era María Eugenia una mujer joven, y ambos términos -mujer- $y$-joven- lo dicen todo, respecto a una Universidad de hace más de seis lustros en que predominaba, entre los profesores, todavía, el estilo del varón patriarcal.

Sobre la primera dimensión, es decir, el contenido docente, resultó que, cuando María Eugenia apareció en nuestra clase madrileña, aquel octubre del 65, acababa de volver de Alejandría, y traía consigo la impronta de todo el mundo árabe moderno, por ella profunda y directamente captado.

El profesor universitario debe -es su deber y su marca- conectar al alumno con las fuentes del saber, y ella nos aportaba, día a día, esas fuentes frescas, vitales y actuantes de lo árabe, 
que nos deslumbraban y que nos marcaban con tal huella... porque afectaban de verdad al ejercicio de construcción de nuestras vidas.

¡Yo no sé qué habría sido de nosotros sin aquellas pruebas reales y elocuentes de la cultura árabe contemporánea!

Mis compañeros y yo le debemos el descubrimiento luminoso e imprescindible de la literatura árabe moderna, a ella y a Pedro Martínez Montávez, del cual también tenemos tanto que decir. Ambos -entre tantos otros hechos memorables-organizaron e impartieron un curso sobre Literatura Árabe en el Ateneo, ¡qué bien lo hicieron! Y ahí están, además, las primeras publicaciones suyas a las que accedíamos, y que nos abrían un mundo, en la colección "Autores Árabes Contemporáneos", patrocinada por el Instituto Hispano-Árabe de Cultura. Y hay muchas gestas más, que todos sabemos, y que la llenan de méritos.

Leo estos días un ensayo-novela de Javier Marías, y encuentro un párrafo que me ha provisto de algunas claves, en torno a lo que ahora trato; habla Javier Marías acerca de "profesores atemporales que tanto se engañan sobre su quehacer y tan poco sobre su sino (su espíritu siempre usufructuario)"1.

Y todos estos calificativos de Javier María evocan -en esta caso- lo contrario exactamente, son el pleno contraste de la imagen de la profesora Gálvez, y de mi captación de tal imagen, pues, desde que la conozco, la he visto expresar, regalar, una modernidad activa que beneficia a sus alumnos; ya lo he dicho al principio. Sobre la segunda advertencia, he de declarar que siempre la encuentro opinando y actuando desde la clarividencia máxima acerca de sus quehaceres universitarios. Y en cuanto a la tercera advertencia general de Javier Marías sobre la tentación usufructuaria desde el parapeto docente, no sólo no pertenece -ni de lejos- tal rutina al estilo de Gálvez Vázquez de Presedo, sino que su negación implícita y explícita de lo 'usufructuario' es lo que -claro está- explica profundamente, y honra, su acto de altruismo enorme al retirarse ahora voluntariamente. Con ello, es manifiesto que no quiere -interpretoexprimir a su favor las ventajas del status, y que decide abrir paso a los que detrás vienen, en esta hora de tantas demandas.

Todo esto significa que la profesora Gálvez posee la tríada de virtudes desde la Universidad más estimables, tres cualidades modélicas: frente a la 'atemporalidad', la vitalidad de su cultura; frente al error en el quehacer, la clarividencia de su talento; frente al abuso desconsiderado, la generosidad de su estilo abriendo paso.

Siempre pienso que la Universidad es uno de los entornos donde mejor puede -o podríamadurar y enriquecerse el ser humano. Y, para eso, los universitarios necesitamos de modelos magistrales. Eugenia Gálvez lo sabe también, y pone siempre de su parte sus tres virtudes universitarias esenciales, para guía de todos. Éste es mi testimonio sincero. Enhorabuena, y muchas gracias.

${ }^{1}$ En Negra espalda del tiempo. Madrid, Alfaguara, 1998, p. 17. 